\title{
"Para a boa ordem e decoro de minha corte" O decoro no vocabulário político do século XVIII português
}

\section{"For the Good Order and Decorum of my Court" \\ Decorum in Portuguese $18^{\text {th }}$ Century Political Vocabulary}

Antonio Cesar de Almeida SANTOS*

Resumo Neste texto, pretendo apresentar uma discussão sobre o uso e os significados da palavra decoro no contexto da cultura letrada portuguesa do século XVIII, considerando a hipótese de que o vocabulário de uma determinada sociedade permite acesso à realidade histórica desta mesma sociedade. A partir de documentação variada e de bibliografia concernente ao assunto, adoto uma perspectiva que leva em conta quem se utilizava dessa palavra - decoro -, em que situações e com que intenção. Igualmente, utilizei a noção de representação como parte da estratégia para alcançar o sentido atribuído por diferentes agentes àquela palavra. Como resultado, pude encontrar uma estreita relação com o preceito retórico da adequação (o decorum latino), presente em Cícero e em outros autores da Antiguidade, cujas obras circularam naquele contexto intelectual, alcançando, especialmente, o domínio da política, como ficou manifesto no episódio da expulsão da Companhia de Jesus de Portugal e de seus domínios.

Palavras-Chave Ilustração, Portugal, decoro

\footnotetext{
* https://orcid.org/0000-0002-3176-6362

Universidade Federal do Paraná, Departamento de História

Rua Gal. Carneiro, 460, 80060-000, Curitiba, PR, Brasil

acsantos@ufpr.br
} 
Abstract In this text, I intend to present a discussion about the use and the meanings of the word "decorum" in the context of the Portuguese literate culture of the 18th century, considering the hypothesis that the vocabulary of a given society allows access to the historical reality of that same society. From a varied documentation and bibliography on the subject, I adopt a methodological perspective that takes in consideration who used this word - decorum -, in which situations and with what intent. Likewise, the notion of representation is seen as part of the strategy to achieve the meaning attributed by different agents to that word. With that, I was able to find a new relationship as a rhetorical precedent of adequacy (or Latin decorum), present in Cicero and other authors of Ancient History, whose works circulate in an intellectual context, reaching mainly the domain of politics, as it was manifest in the expulsion episode of the Society of Jesus from Portugal and its domains. KEYwords Enlightenment, Portugal, Decorum

Em 1744, foi impressa e publicada uma "instrução" ${ }^{1}$ redigida pelo $9^{\circ}$ conde de Vimioso, D. José Miguel João de Portugal, a seu filho segundo, D. Manoel José de Portugal. A publicação desse texto de caráter familiar, após receber "todas as licenças necessárias" - do Santo Ofício, do Ordinário e do Paço -, pode ser explicada em razão de D. José Miguel assim como seu pai, o $2^{\circ}$ marquês de Valença, D. Francisco de Paula de Portugal - fazer parte da Academia Real da História Portuguesa, na qual ingressara em 1731, com cerca de 25 anos de idade. Essa instrução, assim como outra, que ele havia dirigido ao seu primogênito

1 Conforme José Adriano de Freitas Carvalho (2004, p. 333), essas “instruções” de caráter familiar podem ser classificadas "na moldura da arte epistolar" e se constituem em "uma série de conselhos que alguém, geralmente o pai, dá a seu filho herdeiro - englobando, algumas vezes, também o secundogénito - quando está para iniciar a sua carreira de serviço ao rei". No geral, tais "instruções" abrangem uma grande "variedade de situações e atitudes que vão desde os deveres religiosos às obrigações militares, passando pelo jogo, pelas cortesias, pelo comportamento para com as damas, por gestos a evitar, pela pontualidade, pelas expectativas de recompensa de serviços", entre outras. 
e publicada em 1741, mostrava sua dedicação às letras e, particularmente, à história, pois, em ambas, narrou ações de seus antepassados (PORTUGAL, 1741).

$\mathrm{Na}$ instrução que ofereceu ao seu filho segundo, D. José Miguel indica que ele estava destinado "a servir a Igreja e ilustrar a Pátria". Assim, enquanto o pai propôs ao primogênito - que seguiria a carreira das armas - que ele tomasse

por modelo das suas ações as de sete Condes de Vimioso nossos ascendentes, a vós vos proponho por exemplar das vossas as de cinco Eclesiásticos que houve na nossa família, os quais não só mereceram a dignidade Episcopal, mas se fizeram ainda mais beneméritos depois dela. (PORTUGAL, $1744, \mathrm{~s} / \mathrm{p})$

Um dos religiosos escolhidos como exemplo de virtudes morais e cívicas foi o bispo de Lamego, D. Miguel de Portugal e Castro, filho do $4^{\circ}$ conde de Vimioso, D. Luiz de Portugal. Após estudar na Universidade de Coimbra, onde obteve o grau de doutor em Teologia e Cânones, D. Miguel ocupou diversos cargos ligados à Igreja e, em 1636, D. Filipe IV, de Espanha, indicou-o para o bispado de Lamego, sendo confirmado pelo papa Urbano VIII. Sua nomeação, conforme D. José Miguel, deu-se pelo "merecimento da sua pessoa, apesar da herdada oposição" (PORTUGAL, 1744, p. 45) dos espanhóis para com sua família.

Com a Restauração, D. João IV enviou-o para Roma, como seu embaixador, onde permaneceu entre abril de 1641 e dezembro de 1642. Conforme o relato de D. José Miguel, o bispo levou consigo "cinquenta e três criados nobremente vestidos" e, durante o tempo em que desempenhou suas funções, "se portou com a ostentação que convinha a quem queria ser recebido na cabeça do mundo por Embaixador de um Príncipe que ainda nela não estava reconhecido por soberano" (grifo do autor). Durante sua estadia em Roma, D. Miguel viveu diversas situações, 
que foram narradas para demonstrar que, com suas ações, ele "logrou a fortuna de ser amado do povo e Nobreza Romana" além de manter “ilesa a autoridade do seu ministério" (PORTUGAL, 1744, p. 43-54).

Conforme Ana Luísa de Castro Pereira Gomes (2016, p. 74), Portugal "buscou seu lugar no palco da diplomacia moderna" no período imediato à Restauração, visto a necessidade de legitimação de D. João IV como soberano e de normalização de relações com as cortes europeias. Para buscar tal efeito, foram enviados embaixadores para França, Inglaterra, Holanda, Suécia, Dinamarca, Catalunha e Santa Sé, onde Portugal enfrentou grandes dificuldades, pois a embaixada espanhola atuou "no sentido de Roma não reconhecer a Casa de Bragança, como casa soberana". Quando D. Miguel chegou à corte papal, "foi-lhe recusado o estatuto de Embaixador, bem como o carácter ${ }^{2}$ que lhe atribuíra D. João IV, razão pela qual o bispo de Lamego não logrou ser recebido pelo papa Urbano VIII" (CLUNY, 2006, p. 53). Essa situação não foi relatada pelo conde de Vimioso na instrução a seu filho; contudo, referiu-se a dois episódios envolvendo a figura do pontífice: no primeiro, D. Miguel havia solicitado uma

audiência ao Papa para tratar alguns negócios do seu Bispado e, concedendo-a ele com a condição de ir sem nenhum dos criados com que costumava andar pela Corte, a não quis aceitar, e se privou das honras da sua pessoa por não diminuir as do seu carácter. Depois desta ação, em que acudiu ao seu decoro, fez outra em que atendeu ao do mesmo Pontífice; porque mandando-lhe que fosse à sua presença como quisesse, lhe resistiu duas vezes com a resposta de estar já com vestido de campanha para fazer jornada; e deste modo desobedeceu ao Papa com maior veneração do que se lhe obedecesse. (PORTUGAL, 1744, p. 49-50. Grifos do autor)

2 Ver adiante o significado da palavra "carácter". 
Como indicado, D. Miguel portava-se "com a ostentação que convinha" a um embaixador. Conforme Pedro Cardim (2004, p. 29, p. 33, p. 39), no século XVII, "a diplomacia costumava confundir-se com grandes missões de ostentação”, o que, certamente, derivava da origem social dos indivíduos que desempenhavam as funções de embaixador, cargo geralmente atribuído a um nobre titulado, por ser pessoa que saberia "comportar-se e adaptar-se a cortes estrangeiras, bem como representar condignamente o seu senhor" (grifo do autor). É neste âmbito que se pode compreender a mencionada atitude do bispo de Lamego, que se recusou a visitar o papa por não poder estar acompanhado de seus criados, o que diminuiria as honras inerentes ao "carácter" da representação de que fora investido pelo seu soberano. Entretanto, como apontado, a Santa Sé não o reconhecia como embaixador - nem mesmo D. João IV era tido como um soberano legítimo -, o que lhe impedia de "aspirar a uma audiência pública" (CLUNY, 2006, p. 69).

O "carácter" de um diplomata definia o seu estatuto junto à corte para a qual havia sido nomeado: embaixador (ordinário ou extraordinário), ministro plenipotenciário, enviado especial (ou extraordinário), residente ou encarregado de negócios. ${ }^{3}$

Quando usada no singular, a expressão 'ter carácter' ou 'com carácter' designava, geralmente, uma dignidade concedida por uma entidade política reconhecida internacionalmente, dignidade essa que era estabelecida pela 'carta de crença' ou 'credencial', e que colocava o seu titular ao abrigo do direito ius gentium. (CARDIM et al., 2005, p. 280)

3 "Para missões de representação ao mais alto nível - ou seja, embaixadas extraordinárias eram sempre escolhidas figuras de primeira nobreza da corte. Para missões que envolviam negociações com uma acentuada componente técnica era costume chamar letrados. No caso de se tratar de um posto onde as matérias comerciais fossem predominantes, a Coroa procurava contar com chefes de missão com o 'carácter' de residente, de agente de negócios ou de cônsul" (CARDIM et al., 2005, p. 311). 
O estatuto de que se estava investido exigia, por sua vez, que se procedesse de acordo com a sua posição. Como vimos, D. Miguel demonstrou, ou procurou demonstrar, sua posição por intermédio de atos de ostentação, o que era usual para a época. José da Cunha Brochado deixou diversas notas acerca do comportamento do embaixador D. Luís Álvares de Castro, $2^{\circ}$ marquês de Cascais, durante o período em que serviu na embaixada portuguesa em Paris (1695-1704). ${ }^{4}$ Em 1696, Brochado registrava que o "Senhor Embaixador anda logrando grandes aclamações e vivas e são frutos que colhe dos grandes gastos que tem feito" (citado por GOMES, 2016, p. 78). Contudo, os exageros também provocavam alguns insucessos e mal entendidos, como o que ocorreu quando o mesmo embaixador procurou visitar Jaime II, que se encontrava exilado na França. Em seu deslocamento, D. Luís

levou todo o estado, que se compunha de carroças da sua entrada com estribeiro, e pajens a cavalo. Entrou no pátio, e chegando o seu coche à porta principal da escada e quatro (sic) d'El-Rei lhe foi dito, que ele estava indisposto. (...) Porém a razão principal, que havia para não ir ver em cerimônia El-Rei Jacques ${ }^{5}$, era por ser indigno que S. Majestade reconhecesse no mesmo tempo por seus Ministros dois reis de Inglaterra. (BROCHADO citado por GOMES, 2016, p. 80)

$\mathrm{Na}$ ocasião, Jaime II portou-se da maneira adequada à sua posição, evitando que a visita do embaixador português produzisse possíveis repercussões negativas. Sua situação não lhe permitia receber a visita oficial de um embaixador estrangeiro, o que ficava manifesto pela comitiva de D. Luís Álvares de Castro. De certo modo, trata-se de

4 Inicialmente, José da Cunha Brochado foi nomeado secretário da embaixada; mas, em 1698, seu estatuto foi alterado, passando a ser "enviado extraordinário para a corte de Paris, função que ocupou até 1704. (...) O carácter de enviado era o posto máximo que Brochado poderia assumir no palco da diplomacia portuguesa, uma vez que não pertencia à grande nobreza" (GOMES, 2016, p. 82, p. 84).

5 Grafia francesa para o nome inglês James (Jaime). 
uma situação que pode ser comparada àquela que teria sido vivida por D. Miguel, em Roma, quando ele deixou de visitar o papa, porque não quis abrir mão de seu séquito, o que lhe conferia o estatuto de embaixador, não apenas o de bispo.

Conforme Isabel Cluny (2006, p. 176), as demonstrações de luxo dos embaixadores estavam relacionadas à

situação ambígua que estes, ao serem nomeados, acabavam por viver. Convencidos da importância da política externa, como forma suprema do exercício da soberania, consideravam-se os representantes dessa mesma soberania. Ora, representar o soberano implicava dignificar a sua imagem perante os povos que os recebiam. (Grifo do autor)

"Representar o soberano" significava colocá-lo na presença de um outro príncipe, ainda que estivesse fisicamente ausente. Segundo Abraham de Wicquefort, "o embaixador, na qualidade de representante de seu monarca, deveria ser uma figura fiel a este" (GOMES, 2016, p. 75). Por seu turno, Emmerich de Vattel, em meados do século XVIII, indicava que

Todo ministro representa de algum modo o seu superior (...). O que se chama o caráter representativo por excelência é a faculdade que tem o ministro de representar o seu soberano, quanto à sua própria pessoa e quanto à sua dignidade. (VATTEL, 2004, p. 632-633. Grifo do autor)

Percebe-se que representar é uma noção revestida de grande importância na atividade diplomática nos séculos XVII e XVIII. Em texto do final dos anos 1980, Roger Chartier (1991, p. 184) afirmou que "para o historiador das sociedades de Antigo Regime, construir a noção de

6 Trata-se de Abraham de Wicquefort, que redigiu Memoires touchant les ambassadeurs et les ministres publics (1677) e L'Ambassadeur et ses fonctions (1675). 
representação como o instrumento essencial da análise cultural é investir de uma pertinência operatória um dos conceitos centrais manuseados nestas sociedades". Para apontar a presença e o uso desse conceito naquele contexto, Chartier fez referência ao "Dicionário universal de Furetière em sua edição de 1727”. Em Portugal, também nas décadas iniciais do século XVIII, o padre Rafael Bluteau (1720, p. 264-265) registrou que representação era um "termo forense", explicando que ela ocorre "quando pela autoridade, que dá o Direito, se representa aquele que na realidade não está presente". ${ }^{7}$

Chartier (1991, p. 184) também apontou para a existência de dois sentidos aparentemente contraditórios para o termo: "por um lado, a representação faz ver uma ausência (...); de outro, é a apresentação de uma presença, a apresentação pública de uma coisa ou de uma pessoa". Ou, como comentou Francismar Carvalho (2005, p. 153), acerca da posição de Chartier:

as representações tornam presentes um objeto, conceito ou pessoa ausentes mediante sua substituição por uma imagem capaz de representá-los adequadamente. (...) Por outro lado, as representações demonstram uma presença nas apresentações públicas de si mesmo. (...) Esses postulados revelam uma potencialidade explicativa com relação à teatralização da vida no Antigo Regime. (Grifo do autor)

Teatralização é como se pode designar as cenas de ostentação promovidas pelos embaixadores. Contudo, interpretar o papel de embaixador, mostrando-se publicamente, deveria obedecer a certas exigências: além de atender ao decoro que sua figura pública exigia, precisava dignificar a imagem do seu soberano, o qual, conforme Richelieu, precisava conservar a sua boa reputação. Em seu Testamento político

7 Para a palavra representante, Bluteau (1720, p. 264) define apenas como sendo aquele ou aquela que "representa comédias". 
(provavelmente redigido na década de 1630), o ministro do rei francês Luís XIII afirmava que "o príncipe deve ser poderoso pela sua reputação", e que seus ministros deveriam zelar por ela (RICHELIEU, 1996, p. 242-243).

Mas, o que vem a ser, ou a significar, a palavra decoro, para a sociedade portuguesa, no século XVIII? Mary del Priore e Márcia Pinna Raspanti (2018) entendem que "o conceito de decoro" era alvo de preocupação constante nas sociedades portuguesa e luso-brasileira dos séculos XVII e XVIII, mas que ele, nos dias atuais, "adquiriu contornos muito mais sutis e até nebulosos", o que indicaria tratar-se de uma "palavra esquecida". Não obstante considerarem que, naquela época, "qualquer autoridade ou pessoa de destaque na sociedade devia ser guiada pelo decoro", interessa assinalar que o objetivo deste estudo é identificar o significado atribuído a essa palavra naquele contexto. ${ }^{8}$ Trata-se de adotar uma posição que entende que "o sentido de uma palavra pode ser determinado pelo seu uso" (KOSELLECK, 2006a, p. 109). Essa posição também está apoiada em Chartier (1990, p. 17), para quem a identificação das "representações do mundo social" depende de podermos relacionar os "discursos proferidos com a posição de quem os utiliza", e em Mario Molano Vega (2015, p. 170), que propõe: "quem fala, em que contexto e com que intenção, são perguntas básicas que o investigador dos conceitos deve ter em conta". ${ }^{9}$

8 Desde alguns anos, integrantes do Grupo de Pesquisa Cultura e Educação nos Impérios Ibéricos (CEIbero) vem se dedicando ao estudo de termos utilizados no contexto da Ilustração ibérica; consultar GLOSSÁRIO de termos setecentistas. In: Grupo Ceibero. Disponível em: $<$ https://ceibero.wordpress.com/>. Acesso em: 03 ago. 2021.

9 Trad. livre do autor: "Quiénes hablan, en qué contexto y con qué intencionalidad, son preguntas básicas que el investigador de los conceptos deberá tener em cuenta". 


\section{COLOCAR EM BOA ORDEM, COM ENGENHO E DECORO ${ }^{10}$}

Para o início do século XVIII, Rafael Bluteau (1713, p. 29) fixou o significado de decoro como aquilo "que é digno de qualquer pessoa e do lugar que tem, e tão proporcionado ao seu estado, que nem exceda às suas forças, nem seja inferior à sua qualidade”. O verbete é bastante extenso, com várias referências a Cícero, utilizado para abonar o uso da palavra em diversas situações. Ao final do mesmo século, Antonio de Moraes Silva (1789, p. 365) definiu decoro como "honra, respeito devido a alguém por seu nascimento, ou dignidade; a conveniência das ações e outras exterioridades com o carácter [a qualidade] da pessoa" (grifo do autor). ${ }^{11}$ Silva (1789, p. 365) também indica o uso da palavra como um adjetivo - o que estava ausente em Bluteau -, para designar algo "formoso, honesto, que está bem". Ambos registram o termo decoroso que, para Silva, significava "conforme ao decoro; honroso, decente"; Bluteau $(1713$, p. 29$)$ refere-se a "modesto" como aquilo que é decoroso. Respectivamente, decoro e decoroso derivam do latim decorum e decorus.

Nesta pesquisa, além de estar atento aos significados atribuídos a uma palavra em especial, como encontrado nos dicionários, também procuro observar "todos os nomes ou termos para a mesma coisa ou conceito" (KOSELLECK, 2006b, p. 103); ou seja, entendo ser necessário buscar os significados de uma palavra, assim como sinônimos e sintagmas utilizados em substituição àquela que está sendo estudada. Conforme Koselleck (2006a, p. 111),

10 Acredito ser necessária uma observação sobre a importante obra de Norbert Elias (1994) acerca do "processo civilizador". Entendo que ele se utiliza de uma noção que seria, pode-se dizer, assemelhada ao decoro, ou seja, ele trata da civilidade (civilité), ou das boas maneiras (bienséance). Considero que as boas maneiras (como a civilidade) inscrevem-se no domínio da apresentação (como os indivíduos devem se apresentar e comportar), enquanto o decoro faz parte do domínio da representação, como procuro deixar indicado neste artigo. Assim, optei por não utilizar aqui as proposições de Elias, pois elas poderiam promover alguma confusão em relação ao objetivo deste texto: discutir os usos e os significados da palavra decoro para a sociedade portuguesa do setecentos.

11 Importante lembrar que, nas edições de 1789 e 1813, o objetivo expresso de Moraes Silva foi o de apresentar uma versão atualizada ("reformado e acrescentado") do Vocabulário de Rafael Bluteau. 
a investigação de um conceito não deve ser conduzida exclusivamente do ponto de vista semasiológico, restringindo-se aos significados das palavras e às suas modificações. (...) acima de tudo, a história dos conceitos deve alternar entre a abordagem semasiológica e a onomasiológica. Isso significa que ela deve registrar as diferentes designações para os fatos (idênticos?), de forma que seja possível explicar o processo de cunhagem dessas designações em conceito. ${ }^{12}$

No caso em estudo, em que interessa decifrar o(s) sentido(s) atribuído(s) ao termo decoro na sociedade portuguesa do setecentos, algumas palavras de Teresa Margarida da Silva Orta podem exemplificar esta situação na qual o vocábulo estudado não aparece, mas sim o seu significado, o que ocorre por intermédio de uma expressão que tem um sentido equivalente.

As casadas devem sempre acautelar-se na presença das donzelas, pelo que do exemplo se pode recear: assim é em todas conveniente uma discreta elevação, com que não estimem as liberalidades, nem queiram mais grandeza que o desprezá-las; porque as que desejam mais que o que lhes permite a sua esfera, estado, e possibilidade, têm mais um inimigo para vencer o seu coração. (ORTA citada por MAGALHÃES, 2013, p. 498. Grifo do autor $)^{13}$

12 Nos estudos semânticos, a "perspectiva onomasiológica" parte "do significado (ou conceito) para se chegar ao significante" e, "na perspectiva semasiológica, parte-se do significante para chegar ao significado. (...) Evidentemente, a distinção entre onomasiologia e semasiologia coloca-se como de natureza teórico-metodológica; nos usos da linguagem e, em particular, no ato de criação lexical, ambos os tipos de questões apresentam-se simultaneamente" (MARONEZE; GANANÇA, 2020, p. 207-208).

13 Teresa Margarida da Silva Orta publicou em 1752, sob o pseudônimo Dorotéia Engrassia Tavareda Dalmira, o livro Máximas de Virtude e Formosura com que Diofanes, Clymenea e Hemirena, Príncipes de Thebas, vencerão os mais apertados lances da desgraça; depois, publicado como Aventuras de Diófanes. 
$\mathrm{Na}$ busca pelos sentidos atribuídos às palavras em dado contexto, também é bastante útil levar em conta termos ou expressões com sentidos opostos àqueles que interessa apreender: ${ }^{14}$ indecoroso, portanto, ajuda a compreender o significado de decoroso. ${ }^{15}$

A noção de decoro estava presente em diversas instâncias da sociedade portuguesa do século XVIII, principalmente na política. Todavia, é estranho Rafael Bluteau e Antonio de Moraes Silva não terem feito referência ao decoro como um dos preceitos retóricos, especialmente porque o primeiro toma Cícero como a principal autoridade para abonar as definições que apresenta. ${ }^{16}$

A Retórica era uma das "cadeiras"17 das escolas preparatórias para a Universidade, e a sua importância foi destacada no Alvará de 28 de junho de 1759, que privou os padres jesuítas das escolas que mantinham em Portugal e nos demais territórios sob domínio luso.

Porquanto o estudo da Retórica, sendo tão necessário em todas as ciências, se acha hoje quase esquecido por falta de professores públicos que ensinem esta Arte segundo as verdadeiras regras (...). E porque sem o estudo da Retórica se não podem habilitar os que entrarem nas Universidades para nelas fazerem progresso. ${ }^{18}$

14 A abordagem utilizada neste estudo encontra-se mais detalhada em Santos (2021); ver também Lima (2012).

15 Fátima Ferreira (2011, p. 33), por exemplo, em estudo sobre o conceito de ordem, refere-se a "uma tendência antiga na semântica do vocábulo: a sua contraposição dicotômica a um vocábulo oposto, em um percurso que passa pela oposição à desordem, à anarquia e à revolução".

16 Rafael Bluteau (1720, p. 305) define Retórica como "a arte de falar com propriedade e elegância, inculcando boas razões para provar e persuadir os ouvintes"; apresenta os diferentes gêneros (demonstrativo, deliberativo e judicial), mas não trata dos preceitos retóricos. Antonio de Morais Silva (1789, p. 346) apenas define "Rhetorica" como "a arte de falar bem para persuadir os ouvintes".

17 Conforme Bluteau (1712, p. 30), trata-se de uma "cadeira de mestre, de professor público", do latim Cathedra.

18 Alvará para a reforma e restauração dos estudos destes Reinos e Domínios, 28 jun. 1759. In: SILVA, 1830, p. 677. 
Luís Antonio Verney (1713-1792), no seu libelo contra o ensino jesuítico como praticado até meados do setecentos, defendeu a necessidade do aprendizado da Retórica para a comunicação entre as pessoas, entendendo-a como a

Arte de persuadir: e por consequência que é a única coisa que se acha e serve no comércio humano, e a mais necessária para ele. Onde, quem diz que só serve para persuadir na cadeira ou no púlpito conhece pouco o que é Retórica. (...) o discurso de um homem despido de todo o artifício não pode menos que ser um Caos. Poderá ter boas razões, excogitar provas muito fortes, mas se as não sabe dispor com ordem, quem poderá entende-lo? ${ }^{19}$ (VERNEY, 1746, p. 125-126)

Conforme André Sekkel Cerqueira (2016, p. 144), "nos séculos XVI e XVII", a noção de decoro na oratória e na escrita foi "retomada principalmente dos tratados de Cícero". ${ }^{20}$ Mas, ainda no final do século XVIII, o orador romano continuava sendo reconhecido como "sábio nos segredos da sua arte", ensinando "tudo quanto baste nesta matéria; o que nós abraçamos como doutrina de mestre” (FONSECA, 1785, p. 7).

Mesmo em uma sociedade na qual a cultura escrita já estava bem estabelecida, ${ }^{21}$ a arte de falar bem, visando à persuasão ou ao

19 Verney (1746) dedica duas seções de seu livro para tratar da Retórica: Carta 5a (p. 124-152) e Carta 6a (p. 153-214). Em lugar de edição mais recente, preferi utilizar a versão digital disponibilizada pela Biblioteca Nacional de Portugal; trata-se de um exemplar da segunda edição (ver MARTINS, 2012, p. 358).

20 André Sekkel Cerqueira, para suas afirmações, recorre a Luisa Lópes Grigera, que indica: "Granada adota o conceito de Cícero, para quem o decoro relaciona aquilo de que se fala, quem fala e para quem se fala. Ou seja, por causa do decoro devia-se adequar a elocução à matéria, ao emissor da mensagem e ao receptor da mesma". (LÓPES GRIGERA, 1994, p. 124). Trad. livre do autor: "El concepto de Cicerón, de que el decoro se corresponde a la cosa de que se habla, a quien habla y a quien se habla, lo recoge Granada. Es decir que por razón del decoro se debía adecuar la elocución a la materia, al emisor del mensaje y al receptor del mismo".

21 No contexto das Luzes portuguesas, a palavra escrita (impressa ou manuscrita) manifesta-se "nas instituições de poder, nas estruturas de comércio e nas formas de sociabilidade letrada ou científica". Assim, a cultura escrita está presente em variados tipos de impressos e no "vasto 
convencimento, ${ }^{22}$ continuava sendo vista como necessária; era importante saber como se dirigir às pessoas, fosse em uma conversação ou em um sermão. Afinal, como o objetivo era o de mobilizar quem ouvia os discursos, esses deveriam seguir "o decoro prescrito à matéria" (ANDRADE, 2006, p. 131), o qual, articulando-se a outros preceitos retóricos, como a proporção (ou medida), produzia um bom discurso, bem organizado. Conforme João Adolfo Hansen (2013, p. 15),

na instituição retórica, todos os atos discursivos mobilizam preceitos genéricos e apenas indicativos do que deva ser o discurso bem feito, como os de méson ou proportio ou commensuratio, medida ou proporção; prépon ou decorum, decoro; eikós ou verisimilis, verossimilhança.

O decoro, ao definir "a conveniência do discurso à matéria tratada, às pessoas que o ouvem e à situação em que é recebido" (HANSEN, 2013 , p. 33. Grifo do autor), conformava um discurso proporcionado e honesto (adequado). Nas palavras de José Anastácio Fonseca (1785, p. 16-17), estudante do Real Colégio de Mafra, seriam necessários quatro atributos para elaborar um bom discurso,

a saber: Elegância, Composição, Dignidade e Decoro. O primeiro está todo em falar pura e claramente; o que cumpre aquele orador que foge das palavras antigas, quando não as precisa (...). O segundo está na boa colocação das mesmas palavras que se adotam, dando-lhes ordem, união e número (...). Consiste o terceiro nas figuras da Retórica, que não devem ter este nome se carecem de força e graça. Usa-se, enfim,

volume de documentos produzidos para a administração dos territórios" sob domínio luso (SANTOS; DENIPOTI; FONSECA, 2020, p. 578, p. 580).

22 Fernando Nicolazzi (2013, p. 69) - com quem concordo - entende residir uma diferença entre persuadir - "uma 'relação de força' em mão única, espécie de imposição àquele que é persuadido" - e convencer, "uma prática com dupla direção", na qual emissor e receptor desempenham papéis ativos. 
do quarto, apropriando os estilos diversos de falar as Causas, e ainda às partes diversas das mesmas Causas, segundo pede a sua grandeza ou vulgaridade. (Grifos do autor)

Em relação ao âmbito da política, deve-se levar em conta, para o contexto em estudo, a referida presença de uma "teatralização da vida no Antigo Regime" (CARVALHO, 2005, p. 153), notadamente quando se tratava de representar a imagem do soberano.

$\mathrm{O}$ reinado de $\mathrm{D}$. João $\mathrm{V}$ foi pródigo nas exibições de pompa e suntuosidade, evidenciadas tanto na construção de templos e palácios quanto nas celebrações e festividades. Através desses "espetáculos" visuais, permanentes ou episódicos, buscava-se construir uma imagem do Rei capaz de transmitir aos súditos sua magnificência, ou seja, poder e liberalidade. (PAES, 2008, p. 3)

Maria Paula Paes (2008, p. 4) também ressalta que para a "época existia uma rígida doutrina retórica e poética que ordenava as representações e estabelecia o decoro", adequando o que estava sendo apresentado às qualidades do que se queria mostrar; em geral, o poder e soberania régios.

A ideia de adequação das representações, do que (ou de quem) está sendo representado, é central. O mesmo ocorre em relação à arquitetura da época, orientada por leituras que arquitetos italianos do Renascimento fizeram dos antigos tratados consagrados à matéria. Para Vitrúvio (1997, p. 12-14), contemporâneo de Cícero, a boa arquitetura precisava observar os preceitos da "ordem" (ordenação), "disposição", "euritmia ou proporção (simetria, decoro)" e "distribuição", indicando que "o decoro é o aspecto correto da obra, que resulta da perfeita adequação do edifício não existindo nada que não esteja fundado em alguma razão". ${ }^{23}$ Cícero (1999, p. 67-68) também dedicou algumas linhas

23 Trad. livre do autor: "El decoro es el aspecto correcto de la obra, que resulta de la perfecta adecuación del edifício en el que no haya nada que no esté fundado en alguna razón". 
do De Officiis para expor "como deve ser a casa de um homem honrado e estimado", a qual deve contemplar a "utilidade", "sem descurar do conforto e da dignidade".

Passando para o século XV, Alexandre Ragazzi (2017, p. 8-7) indica que Leon Battista Alberti (1404-1472) "estendeu os compromissos formais do conceito de concinnitas à sua própria teoria e prática arquitetônicas", explicando que "as letras de Cícero (106-43 a. C.) representaram a máxima expressão desse conceito", que pode ser traduzido pela observância da "proporção e harmonia entre as partes componentes de um todo". Para Alberti, "toda graça e todo decoro" eram constituídos pela adoção do princípio da concinnitas, responsável pela elegância da construção, que precisa apresentar as seguintes qualidades: "utilitas, firmitas, venustas et decor" (utilidade, firmeza, beleza e ornamento) (ARNAU AMO, 1988, p. 124, p. 107).

De cunho mais prático, o tratado sobre as Regras das cinco ordens de arquitetura (1562), de Giacomo Vignola (1507-1573), também fez parte do aprendizado de arquitetos portugueses. Para Vignola, as ordens de arquitetura conduziriam a um "arranjamento regular e simétrico das diferentes partes que servem a decorar um Edifício, de cuja mistura resulta um todo formoso e proporcionado" (ANDRADE, 1787, p. 49). ${ }^{24}$

Além da construção dos edifícios, a disposição deles e das ruas e praças das povoações também deviam observar as regras do decoro. Em seu Tratado da ruação (ca. 1760, fl. 3), José de Figueiredo Seixas saudava o plano de reconstrução de Lisboa, especialmente o

24 A presença das ideias de Vignola em Portugal é manifestada em um curto texto manuscrito presente em códice da Coleção Pombalina (Biblioteca Nacional de Portugal), ainda que não se possa determinar a data de sua elaboração (mas que, pela grafia, seria anterior ao século XIX) ou seu autor: "Vignola foi hum Homem Italiano de Nação com muitos talentos para a Architetura, o qual compoz hum Livro das cinco Ordens com regras tão claras, que tem tido huã geral aceitação dos Architetos". BIBLIOTECA NACIONAL DE PORTUGAL, Lisboa. Dialogo sobre as artes: Hum Padrinho, e o seu afilhado. Coleção Pombalina, Códice 686, fls. 720-728. 
seu novo e grandioso ruamento, a espaçosa largura das ruas, a direitura delas, o bem proporcionado comprimento de cada uma, terminado pelas ruas travessas, a conveniente largura dos chãos de casas e a da altura dos seus andares, a uniformidade das frontarias, os grandiosos canos gerais dos despejos, o plano dos pavimentos nas calçadas exaltando vales e aplainando montes. (Grifos do autor)

Seixas também defendia que a implantação de ruas e praças deveria ter em conta "a dignidade da povoação, cidade, vila ou lugar" (fl. 41). Décadas antes, o padre jesuíta Luiz Gonzaga, em seu tratado Exame militar de 1703, definiu decoro como a adequação "da edificação ou da povoação" a fatores relacionados ao "sítio de implantação, tradições construtivas e finalidade da obra" (BASTOS, 2016, p. 99). ${ }^{25}$

No domínio da pintura, desde o século XVI, pelo menos, a noção de decoro também esteve presente, traduzida no entendimento de que o conjunto representado precisava estar em harmonia. Francisco de Holanda, no seu tratado Da Pintura antiga (1548), dedicou um capítulo ao "decoro" e à "decência", explicando: "o que chamo decoro na pintura é que aquela figura ou imagem que pintamos, se há-de ser triste ou agravada, que não tenha ao redor jardins pintados nem caças, nem outras graças e alegrias" (HOLANDA citado por LOUSA, 2013, p. 232).

Conforme o que vem sendo exposto, pode-se relacionar a noção de decoro ao preceito retórico ciceroniano de adequação. Entretanto, como indicado, Rafael Bluteau, apesar de utilizar Cícero para abonar suas definições, considera o termo apenas no domínio da moral. Ou seja, no lugar do De Oratore, ganhou relevo o De Officiis, texto redigido um ano antes de sua morte.

25 "Aparência, Decoro, e Fermosura da planta, ou praça, (...) he a propriede [propriedade] das partes da praça por ordem ao sitio, q se tem escolhido, por ordem ao costume com q se dispoem, e per ordem a natureza do com q se faz. (...) e a planta, q representa tudo isto se diz decorosa." (GONZAGA citado por BASTOS, 2016, p. 99) 
Em relação à presença do De Officiis na sociedade portuguesa do setecentos, é necessário registrar uma tradução desse texto publicada em 1766: Os tres livros de Cicero sobre as obrigações civis traduzidos em lingua portugueza para uso do Real Collegio de Nobres. ${ }^{26}$ Todavia, diversas obras de Cícero circularam em Portugal desde o século XV, a maior parte em latim, mas algumas delas em traduções para o castelhano e para o francês, como foi possível identificar em consulta ao acervo da Biblioteca Nacional de Portugal. Diversos textos ciceronianos foram impressos em latim, em Lisboa ou em Coimbra e, dentre eles, houve algumas edições do De Officiis.

Segundo Jorge Alves Osório (1985/1986), para os séculos XV e XVI, é possível identificar a tradução de três textos de Cícero para o português: além do De Senectute, por Damião de Góis, cuja publicação ocorreu em Veneza, em 1538, "em língua portuguesa, existiam já versões do De Officiis e do De Amicitia" (OSÓRIO, 1985/1986, p. 212). Esse último, em tradução de Duarte de Resende, foi publicado em 1531; o anterior permaneceu como manuscrito, e sua tradução é atribuída ao infante D. Pedro (1392-1449).

Para D. Pedro avultava a utilidade prática do tratado ciceroniano, isto é a sua utilidade para o novo contexto moral e cultural que decorria também da evolução social e das perspectivas que a nova dinastia portuguesa, com a sua concepção de modelo de monarca e de homem da nobreza, parecia pretender equacionar. (OSÓRIO, 1985/1986, p. 212)

Apesar da boa aceitação do orador romano em Portugal, foram poucas as traduções de suas obras. A edição de 1766 reveste-se de importância por ter sido mandada fazer, segundo o tradutor, por Sebastião

26 A tradução foi realizada pelo italiano Miguel Antonio Ciera, que havia sido contratado como professor de matemática do Colégio Real dos Nobres. Contudo, Ciera não verteu o De Officiis diretamente do latim, utilizou uma versão italiana redigida por Giácomo Facciolati, tomando-a como "a mais correta" (CÍCERO, 1766, s/p). 
José de Carvalho e Melo, o qual, como veremos adiante, manejava a noção de decoro desde a primeira metade do século XVIII. Ainda que não se possa determinar sua circulação e seus efeitos, sabe-se que alguns exemplares dessa edição de 1766 foram remetidos para o Brasil, como ficou indicado em carta de 22 de julho daquele ano, enviada ao governador da capitania de São Paulo. ${ }^{27}$

Cícero escreveu o De Officiis para seu filho Marco, que estava estudando em Atenas, com o propósito de orientá-lo acerca das "obrigações da vida civil", alertando-o que "na observância, ou abandono delas, consiste ou se perde o carácter de homem honrado" (CÍCERO, 1766, p. 3). ${ }^{28}$ Em seu texto, o orador romano destaca aquelas virtudes que ele entende como necessárias para a vida em sociedade, que pressupõe uma ativa participação política; assim, sua exposição busca demonstrar a utilidade do decoro, da moderação, da modéstia, da continência e da temperança para a vida pública. Como destacou Manuel Blanco Valbuena, responsável por uma tradução do De Officiis para o espanhol, cuja primeira edição, bilíngue, foi publicada em 1777, trata-se de uma obra indispensável para a educação dos jovens, "seja pela propriedade e elegância de seu estilo, como pela doutrina que ensina sobre as obrigações que constituem os homens em bons cidadãos" ${ }^{29}$ (CÍCERO, 1818 , p. i. Grifos do autor).

27 Na referida carta, Sebastião José de Carvalho e Melo, Secretário de Estado dos Negócios do Reino, informava a D. Luís Antonio Botelho de Souza Mourão que estavam sendo enviados "alguns exemplares da Instrução dos Ofícios de Cícero", com a finalidade de "V. Sa. aí formar alguns Homens que sejam Capazes de discernimento e de percepção". ARQUIVO HISTÓRICO ULTRAMARINO, Lisboa. Carta do conde de Oeiras ao Governados da Capitania de São Paulo, 22 jul. 1766. Códice 423.

28 Estou utilizando duas traduções do De Officiis, uma publicada em 1766 e, outra, em 1999. Além do título, os textos apresentam diferenças significativas. No geral, optei por usar a tradução de Miguel Antonio Ciera, em consideração ao contexto no qual ela aparece, o qual mereceu a devida atenção do tradutor, inserindo algumas notas para explicar que "o filósofo não podia falar senão conforme a constituição da terra em que viveu, e das leis que nela havia no seu tempo" (CÍCERO, 1766, p. 22), para referir-se a menções acerca do suicídio (p. 106), do comércio (p. 144), dos "deuses" (p. 154) e dos regimes políticos (p. 20-22).

29 Trad. livre do autor: "Entre todos los libros que nos quedan de los antiguos, apenas se podrá señalar otro mas útil para enseñanza de los jóvenes que se dedican al estudio de la lengua 
Para Cícero, o decoro era virtude inseparável daquilo que fosse honesto, decente e útil: "Usar prudentemente da razão e do discurso, governar todas as ações com cautela, saber conhecer a verdade que há em qualquer coisa, e sustenta-la, tudo isto é decente" (1766, p. 90); o decoro, por sua vez, é "o que convém à natureza de cada um, de maneira que apareça nele a moderação e a temperança com algum ar de gentileza" (1766, p. 92). O decoro também se manifesta pela proporção, e, nesse aspecto, Cícero usa a imagem do corpo humano que, quando proporcionado, gera "formosura", "porque todas as partes respondem uma à outra com bela harmonia" (1766, p. 94). Não obstante a necessidade de agir com moderação, para se conservar "o decoro que é necessário" cada um deve se conduzir "conforme o seu gênio, contanto que não seja vicioso" (1766, p. 105).

Deste modo, poder-se-ão averiguar as obrigações civis, tratando-se de saber o que é decente e apropriado às pessoas, aos tempos e às idades. Sempre, porém, advertindo que o principal decoro depende de uma certa constância em resolver e obrar uniformemente. (CÍCERO, 1766, p. 120. Grifo do autor)

Esses preceitos deveriam ser especialmente observados por aqueles que exerciam funções públicas, pois representavam "a pessoa da $\mathrm{Ci}$ dade", ficando obrigados a sustentarem "a dignidade e decoro da mesma" (CÍCERO, 1766, p. 119). É certo que o antigo cônsul romano não estava se dirigindo diretamente a integrantes da sociedade portuguesa do setecentos; mas, como foi possível apontar, suas ideias não eram desconhecidas, especialmente as que se referiam à noção de decoro na retórica ou no domínio da política.

latina, que este de los Oficios de Ciceron, asi por la propiedad y elegancia de su estilo, como por la doctrina que enseña de las obligaciones que constituyen á los hombres buenos ciudadanos". 
Na censura que o clérigo regular D. Caetano de Gouvea, examinador do Santo Ofício, redigiu, quando examinou a "instrução" que o $9^{\circ}$ conde de Vimioso endereçou a seu filho primogênito, encontra-se uma referência explícita ao Livro I do De Officiis:

E para dizer a V. Eminência o juízo que formo desta grande obra, posto que escrita em tão abreviado volume, me devo lembrar de um admirável pensamento de Cícero, que foi tão grande político como orador, o qual disse: (lib. I. de Offic.) que não se pode fazer nem maior, nem melhor serviço à República, que ensinar e instruir a mocidade, porque da boa educação que os pais dão aos filhos depende toda a felicidade não só das famílias, mas das Repúblicas, dos Reinos e dos Impérios. (PORTUGAL, 1741, s/p. Grifo do autor)

Por sua vez, D. Francisco de Paula de Portugal, $8^{\circ}$ marquês de Valença, pai do autor da instrução familiar acima referida, proclamava ser um "defensor do mais purificado decoro", o qual foi definido por ele como "a modéstia nas palavras, a decência no vestido, a sobriedade na mesa, a escolha das companhias, e amizades" (PAULA citado por CARVALHO, 2004, p. 326, p. 339). Conforme José Adriano de Freitas Carvalho (2004, p. 326, p. 328), D. Francisco de Portugal tomava a noção de decoro a partir de Catão, o Jovem (95-46 a. C.), a quem Cícero (1999, p. 166) se referia como "amigo", apesar de ambos discordarem em alguns assuntos.

A noção de decoro também não ficou ausente das páginas da obra que o capuchinho Frei José de Jesus Maria ofereceu ao infante D. Francisco, irmão de D. João V. Em suas palavras, tratava-se de um texto dirigido a "um varão perfeito", no qual evocava alguns episódios históricos, morais e políticos, referindo-se, entre outros, ao de uma grande "sacerdotisa" que "por falta de cavalos não podia ir ao templo na carroça, e não estava bem ao seu decoro ir a pé”; a Sêneca, que julgava conveniente que os príncipes se "vestissem com esplendor por decoro da Majestade"; e, aos altares e templos, que poderiam ser adornados "com o 
maior primor, e composição reverente, sendo a Deus tudo devido para decoro de sua Divina Majestade, em cuja ação Portugal tanto se esmera" (JESUS MARIA, 1737, p. 54, p. 120, p. 373). E as lições dos retores e moralistas latinos continuaram a ser evocadas na segunda metade do século XVIII, como mostra o médico Duarte Rebelo de Saldanha (1761, p. vii), defendendo que "os que pretendem ensinar devem trazer sempre nas primeiras atenções aquele célebre termo dos Latinos chamado Decorum, que consiste em ensinar a cada um a falar segundo o seu carácter".

\section{Agir CONFOrMe os TEMPOS, OS LUGARES E AS CIRCUNSTÂNCIAS}

Para avançar nesta exposição acerca dos usos e significados da palavra decoro no âmbito da cultura letrada portuguesa do setecentos, vou retomar alguns aspectos ligados à atividade que o já citado Emmerich de Vattel (2004, p. 632) indicou possuir um "caráter representativo por excelência", para designar as ações de embaixadores e de outros "ministros" encarregados de missões diplomáticas.

Em 1744, Sebastião José de Carvalho e Melo, então a serviço da Secretaria de Estado dos Negócios Estrangeiros e da Guerra, ${ }^{30}$ seguiu para a corte austríaca na condição de "emissário", encarregado de mediar um conflito que havia se instalado entre Roma e Viena, e para o qual o papa Bento XIV havia solicitado a intervenção de D. João V junto à rainha Maria Teresa. ${ }^{31}$ Conforme António Lopes (1999, p. 26), Carvalho e Melo partiu no dia 8 de dezembro, via Londres, chegando "ao seu

30 Em 1738, Sebastião José de Carvalho e Melo seguiu para Londres na condição de "enviado extraordinário", permanecendo na corte inglesa até 1744, quando retornou a Lisboa por alegados problemas de saúde. Quando foi designado para Viena, ainda estava formalmente ligado à representação portuguesa na Inglaterra, para onde regressou antes de viajar para a corte austríaca. Em Londres, conforme recomendação do Padre Carbone, informou ao rei inglês "as verdadeiras razões que o levavam ao Império, pois o contrário poderia levantar falsas suspeitas, contrárias aos interesses portugueses." (CORREIA, 1965, p. 34)

31 Ver CORREIA, 1965, p. 31-51. 
destino no princípio de Julho de 1745. A 10 de Julho sabemos que já está em Viena, donde sairá a 3 de Setembro de 1749".

Durante esses pouco mais de quatro anos, além da correspondência mantida com Marco Antonio de Azevedo Coutinho, Secretário de Estado dos Negócios Estrangeiros e da Guerra, trocou várias cartas com jesuítas instalados na corte portuguesa, dentre eles os padres João Baptista Carbone, conselheiro de D. João V, e José Ritter, confessor da rainha D. Mariana. ${ }^{32}$ Nas cartas transcritas por António Lopes (1999) aparecem várias referências ao decoro e à reputação do rei, bem como à decência do seu "emissário", demonstrado a importância destes atributos para aqueles homens que se ocupavam com a apresentação da figura pública do soberano, que era, nas palavras de Vattel (2004, p. 214), aquele que representava "toda a nação, cuja majestade ele reúne na sua pessoa".

Pouco tempo após ter chegado a Viena, Carvalho e Melo manifestou sua disposição em contrair matrimônio com D. Leonor Daun, que pertencia "a uma família de elevada nobreza do Império" (CORREIA, 1965, p. 75). O casamento, após Carvalho e Melo ter obtido licença de D. João V, foi celebrado em dezembro de 1745 e significou "promoção social" a uma pessoa "sem grandes meios de fortuna" (SERRÃO, 1987, p. 48), além de ter agradado a diversas pessoas em Lisboa. Segundo Maria Alcina Correia (1965, p. 78), o casamento propiciou "três factos a seu favor: um pretexto para doravante residir em Viena, uma oportunidade para conseguir o agrado da Imperatriz e um processo de conhecimento público da sua enviatura”.

Apesar dessas pretensas vantagens, apenas em dezembro de 1747 Carvalho e Melo deixou de ser um simples "emissário" e passou à condição de "enviado", uma mudança julgada "estimável” pelo padre Carbone, para quem a promoção devia-se à "grande aceitação que mereceu desses

32 Ver LOPES, 1999, p. 21-25. António Lopes (1999, p. 9) transcreveu 115 cartas e minutas de cartas: "45 são cartas autógrafas dos próprios jesuítas, que já eram desde há muito conhecidas, por se encontrarem na Secção Pombalina da B.N.L., nos Códices 661, 664 e 640. As outras 70 são cópias ou minutas de cartas que Sebastião José enviava aos jesuítas". 
Soberanos e dos seus ministros, e por se achar também com casa e família nesta mesma Corte" (CARBONE citado por LOPES, 1999, p. 312).

Assim como o já mencionado José da Cunha Brochado, o "carácter" de enviado, naquele contexto, era a posição mais destacada que Carvalho e Melo poderia assumir, dado sua origem social. ${ }^{33}$ Hierarquicamente, os embaixadores "ocupavam o primeiro grau de representação", enquanto "os Enviados ocupavam o segundo lugar e o título que lhes era atribuído resultava de uma posição menos qualificada em termos sociais", ainda que detivessem "as mesmas prerrogativas, como o estarem ao abrigo do Direito das Gentes". Em geral, os enviados "não eram designados para missões de representação, sendo a sua função normalmente de negociação", incumbência, aliás, que havia levado Carvalho e Melo a Viena (CLUNY, 2006, p. 43).

Apesar de já não ser o tempo das "missões de ostentação", o enviado português não dispunha de recursos financeiros para se apresentar na luxuosa corte austríaca, tendo sido obrigado a solicitar um empréstimo, antes de partir de Lisboa, "dadas as obrigações da decência com que se devia tratar naquele lugar público" (CARVALHO E MELO citado por SERRÃO, 1987, p. 45). Viena era reconhecidamente uma das cidades mais ricas e caras da Europa, o que exigia grandes despesas daqueles que tratavam dos interesses dos seus soberanos, especialmente porque precisavam se relacionar com outros diplomatas e com o pessoal da administração local.

Na sua vida pública em Viena, Sebastião José de Carvalho e Mello manteve um grande número de relações pessoais constituídas em parte por membros da nobreza austríaca familiares de D. Leonor Daun, diplomatas e enviados de estado, ministros ou funcionários ao serviço da Imperatriz Rainha, e alguns vultos do meio cultural austríaco. (CORREIA, 1965, p. 81)

33 Como sabemos, anos depois, ocupando o cargo de Secretário de Estado dos Negócios do Reino, Sebastião José de Carvalho e Melo recebeu os títulos de conde de Oeiras (1759) e de marquês de Pombal (1770). 
Essas relações pessoais e profissionais ocupavam boa parte da correspondência entre Carvalho e Melo e os padres jesuítas instalados na corte portuguesa. Mas, para o padre Carbone, o decoro do rei era assunto de grande preocupação, como mostra em sua carta de 12 de outubro de 1745, na qual recomendava: "nem a Vossa Senhoria faltarão meios prudentes, com que satisfazer aparentemente à Corte de Roma (quando de lá se insistisse na dita negociação) sem sacrificar o decoro do nosso Monarca" (CARBONE citado por LOPES, 1999, p. 100. Grifo do autor). Igualmente, no curso das negociações de que fora ocupado, Carvalho e Melo manifestava ao mesmo padre, em carta de 31 de maio de 1746, seu cuidado em preservar "aquela alta reputação, que nas Cortes de Roma e Viena, e em toda a Europa, tem estabelecido a magnificência de El Rei Nosso Senhor"; e, em 27 de julho do mesmo ano, reafirmava estar agindo de maneira a assegurar "o decoro e o sossego de Sua Majestade" (CARVALHO E MELO citado por LOPES, 1999, p. 164, p. 186).

Quanto à decência exigida nas apresentações públicas de Carvalho e Melo, ela repercutiria na imagem do seu soberano, pois "o ornato da figura exterior dos Representantes Públicos" mostraria "pela mesma figura a estimação que cada um deles deve a seu Amo", evitando-se que, "por falta de meios para se sustentar", ficasse demonstrada "a pouca estimação que deve a Sua Majestade" (CARVALHO E MELO citado por LOPES, 1999, p. 174). No geral, "o primeiro objeto" que o enviado de D. João V devia observar era "o decoro e o serviço de El Rei Nosso Senhor", agindo "até onde o podia fazer sem o menor prejuízo do seu Real decoro" (CARVALHO E MELO citado por LOPES, 1999, p. 82-83). Afinal, a negociação de que estava encarregado era "matéria de tanta consequência, na qual se interessa o decoro do Soberano, do Ministério, da pessoa de Vossa Senhoria e também da Nação" (CARBONE citado por LOPES, 1999, p. 91). ${ }^{34}$

34 Nas cartas transcritas por António Lopes (1999), Carvalho e Melo e os jesuítas também fazem referência ao indecoro/indecoroso e ao indecente, para afirmar, por oposição, os valores compatíveis com o respeito, fidelidade, reputação e honra devidos ao soberano. 
Para concluir este texto, vamos adentrar o reinado de D. José (1750-1777), um soberano que, explicitamente, declarava agir na defesa de sua fama e de sua reputação, além de se ocupar "com a boa ordem e decoro" de sua corte, como deixou expresso em Alvará de 15 de janeiro de 1759, pelo qual ampliou a chamada "lei dos tratamentos". ${ }^{35}$ Nesse contexto, novamente encontramos Sebastião José de Carvalho e Melo ocupando o cargo de Secretário de Estado dos Negócios do Reino, desde 1756. Muito havia mudado, e os jesuítas já não desfrutavam das mesmas boas atenções que antes. Diversos acontecimentos em que estiveram envolvidos, desde o início do reinado de D. José, fizeram com que os padres da Companhia de Jesus fossem afastados da corte e perdessem influência junto à família real. A situação atingiu um estágio crítico quando, em setembro de 1758, alguns deles foram acusados de conspirarem com os nobres implicados no atentado sofrido pelo rei. Em carta de 19 de janeiro de 1759, D. José informou ao Regedor da Casa da Suplicação que estava adotando medidas enérgicas para a "defesa da minha Real Pessoa e Governo, e do sossego público dos meus Reinos e Vassalos". ${ }^{36}$ Em consequência, diversos jesuítas foram presos e tiveram seus bens e papéis sequestrados, ficando proibidos de se comunicarem com outras pessoas.

A permanência da Companhia de Jesus em solo português logo mostrou-se inviável. Em 03 de setembro de 1759, foi publicada a Lei de expulsão dos jesuítas e, em carta ao Cardeal Patriarca de Lisboa, da mesma data, o rei declarava que os padres daquela Ordem haviam atentado contra a sua "Fama" e sua "Real Reputação", e que, portanto, bani-los era uma providência necessária para preservar o "decoro da Majestade", ou seja, daquela autoridade representada na pessoa do soberano, e que era a "Alma vivificante de toda a Monarquia". ${ }^{37}$

35 Alvará ampliando a Lei dos Tratamentos (29 jan. 1739), 15 jan. 1759. In: SILVA, 1830 , p. 644-645.

36 BIBLIOTECA NACIONAL DE PORTUGAL, Lisboa. Carta régia ao Regedor da Casa da Suplicação, dispondo sobre o sequestro dos bens dos jesuítas, 19 jan. 1759. Disponível em: $<$ https://purl.pt/22611>. Acesso em: 18 abr. 2013.

37 Lei de expulsão dos jesuítas, de 03 set. 1759 e Carta ao Cardeal Patriarca de Lisboa, de 03 set. 1759. In: SILVA, 1830, p. 713-716; p. 718-721. 
$\mathrm{Na}$ argumentação contida na Lei de expulsão e na carta dirigida ao Patriarca de Lisboa, ${ }^{38}$ são destacadas a figura pública do soberano e a autoridade que ele representava, as quais entendia-se que estavam sendo atacadas. Assim, D. José precisava defender a sua própria pessoa - o rei e a soberania que ele representava; ou seja, era sua obrigação tomar as providências para impedir os ataques à sua boa fama e à sua reputação, preservando o "decoro da Majestade" de que estava investido. De certo modo, as lições expostas por Cícero no De Officiis - e que circularam por Portugal, desde o século XV, pelo menos, - parecem ter frutificado, em especial aquela que aconselhava aos que representavam "a pessoa da Cidade" a defenderem "a dignidade e decoro da mesma".

\section{REFERÊNCIAS BIBLIOGRÁFICAS}

ANDRADE, José Calheiros de Magalhães. Regras das cinco ordens de architetura, segundo os princípios de Vignhola ... escritas em francez por ${ }^{* * *}$ e expostas em portuguez por J. C. M. A. Coimbra: Na Real Imprensa da Universidade, 1787. Disponível em: < https://digitalis-dsp.uc.pt/ handle/10316.2/2611 >. Acesso em: 25 mar. 2021.

ANDRADE, Luiz Cristiano de. Os Preceitos da memória: Manuel Severim de Faria, inventor de autoridades lusas. História \& Perspectivas, v. 1, n. 34, p. 107-137, 2006.

ARNAU AMO, Joaquin. La Teoria de la arquitectura en los tratados: Alberti, t. II. Madrid: Tebas Flores, 1988.

BASTOS, Rodrigo. A Arte do urbanismo conveniente: o decoro na implantação de novas povoações em Minas Gerais na primeira metade do século XVIII. Caiana, n. 8, p. 96-104, 2016.

BLUTEAU, Raphael. Vocabulario portuguez \& latino, v. 2. Coimbra: Collegio das Artes da Companhia de Jesus, 1712.

38 A carta dirigida ao Cardeal Patriarca de Lisboa, que havia sido nomeado Reformador da Companhia de Jesus em Portugal pelo papa, repete, em grande parte, os argumentos apresentados na Lei de expulsão. 
BLUTEAU, Raphael. Vocabulario portuguez \& latino, v. 3. Coimbra: Real Collegio das Artes da Companhia de Jesus, 1713.

BLUTEAU, Raphael. Vocabulario portuguez \& latino, v. 7. Lisboa: Pascoal da Sylva, 1720.

CARDIM, Pedro. A Prática diplomática na Europa do Antigo Regime. In: RODRIGUES, Luís Nuno; MARTINS, Fernando (Dir.). História e relações internacionais: temas e debates. Évora: Publicações do Cidehus, 2004. p. 11-53.

CARDIM, Pedro et al. A Diplomacia portuguesa no Antigo Regime: perfil sociológico e trajectórias. In: MONTEIRO, Nuno Gonçalo; CARDIM, Pedro; CUNHA, Mafalda Soares da (org.). Optima Pars: elites iberoamericanas do Antigo Regime. Lisboa: ICS, 2005. p. 277-337.

CARVALHO, Francismar Alex Lopes de. O conceito de representações coletivas segundo Roger Chartier. Diálogos, Maringá, v. 9, n. 1, p. 143-165, 2005.

CARVALHO, José Adriano de Freitas. As Instrucções de D. Francisco de Portugal, Marquês de Valença, a seus filhos. Um texto para a Jacobeia? Península - Revista de Estudos Ibéricos, n. 1, p. 319-347, 2004.

CERQUEIRA, André Sekkel. A Retórica da história no século XVII. LaborHistórico, v. 2, n. 1, p. 137-150, 2016.

CHARTIER, Roger. O Mundo como representação. Estudos Avançados, v. 5, n. 11, p. 173-191, 1991.

CHARTIER, Roger. A História Cultural: entre práticas e representações. Lisboa: Difel, 1990.

CÍCERO, Marco Túlio. Dos Deveres. São Paulo: Martins Fontes, 1999.

CÍCERO, Marcus Túlio. Los Oficios de Ciceron, con los dialogos de la Vejez, de la amistad, las paradojas, y el sueno de Escipion, traducidos por Don Manuel de Valbuena, de las Reales Academias Latina-Madrilense, y Espanhola. Madrid: Imprenta Real, 1818.

CÍCERO, Marco Túlio. Os Tres livros de Cicero sobre as obrigações civis traduzidos em lingua portugueza para uso do Real Collegio de Nobres. Lisboa: Miguel Manescal da Costa, 1766.

CLUNY, Isabel. O Conde de Tarouca e a diplomacia na época moderna. Lisboa: Livros Horizonte, 2006. 
CORREIA, Maria Alcina Ribeiro. Sebastião José de Carvalho e Mello na corte de Viena de Áustria: elementos para o estudo da sua vida pública (1744-1749). Lisboa: Instituto de Alta Cultura, 1965.

ELIAS, Norbert. O Processo civilizador: uma história dos costumes, v. 1. Rio de Janeiro: Jorge Zahar, 1994.

FERREIRA, Fátima Sá e Melo. O Conceito de ordem em Portugal (séculos XVIII e XIX). Tempo, v. 17, n. 31, p. 21-33, 2011.

FONSECA, José Anastácio da Silva e. Conclusões de rhetorica e poetica, apresentadas no Real Collégio de Mafra, aos 13 de julho de 1785. Lisboa: Lino da Silva Godinho, 1785.

GOMES, Ana Luísa de Castro Pereira. José da Cunha Brochado: de secretário de embaixada a embaixador extraordinário. Tempo, v. 22, n. 39, p. 72-87, 2016.

HANSEN, João Adolfo. Instituição retórica, técnica retórica, discurso. Matraga, v. 20, n. 33, p. 11-46, 2013.

JESUS MARIA, José de. Academia singular, e universal, historica, moral, e politica, ecclesiastica, scientifica, e chronologica. Lisboa: Pedro Ferreira, 1737. KOSELLECK, Reinhart. Futuro passado: contribuição à semântica dos tempos históricos. Rio de Janeiro: Contraponto; PUC-Rio, 2006a.

KOSELLECK, Reinhart. Uma Resposta aos comentários sobre o Geschichtliche Grundbegriffe. In: JASMIN, Marcelo G.; FERES Jr., João (org.). História dos conceitos: debates e perspectivas. Rio de Janeiro: PUC-Rio; Loyola; Iuperj, 2006b. p. 97-109.

LIMA, Luís Filipe Silvério. Civil, civilidade, civilizar, civilização: usos, significados e tensões nos dicionários de língua portuguesa (1562-1831). Almanack, n. 3, p. 66-81, 2012.

LOPES, António, SJ. O Marquês de Pombal e a Companhia de Jesus: correspondência inédita ao longo de 115 cartas (de 1743 a 1751). Cascais: Principia, 1999.

LÓPES GRIGERA, Luisa. La Retórica em la España del siglo de oro. Salamanca: Ediciones Universidad de Salamanca, 1994.

LOUSA, Maria Teresa Viana. Francisco de Holanda e a ascensão do pintor. Tese (Doutorado em Belas Artes) - Universidade de Lisboa, Lisboa, 2013. 
MAGALHÃES, Isabel Allegro de (org.). História e antologia da literatura portuguesa - Século XVIII. Lisboa: Fundação Calouste Gulbenkian, 2013. MARONEZE, Bruno; GANANÇA, João Henrique. Perspectivas onomasiológica e semasiológica nos estudos de neologia. LaborHistórico, v. 6, n. 1, p. 204-224, 2020.

MARTINS, Maria Teresa E. Payan. Livros clandestinos e contrafacções em Portugal no século XVIII. Lisboa: Colibri, 2012.

MOLANO VEGA, Mario Alejandro. Reinhart Koselleck, Historias de conceptos. Conceptos Históricos, n. 1, p. 162-181, 2015.

NICOLAZZI, Fernando. O Historiador enquanto leitor: história da historiografia e leitura da História. História da historiografia, n. 13, p. 63-77, 2013. OSÓRIO, Jorge Alves. Cícero traduzido para o português no século XVI: Damião de Góis e o "Livro da Velhice”. Humanitas, v. 37-38, p. 191-266, 1985/1986.

PAES, Maria Paula Dias Couto. O Teatro do controle: O domínio social e político na América Portuguesa da primeira metade do século XVIII. Nuevo Mundo Mundos Nuevos, Colóquio Familia y organización social en Europa y América siglos XV-XX, Murcia-Albacete, 12-14 dic. 2007, 2008. PORTUGAL, José Miguel João. Instrucçam que o conde de Vimioso Dom Joseph Miguel Joam de Portugal, do Conselho de sua Magestade, e Deputado da Junta dos tres Estados dá a seu filho segundo D. Manoel Joseph de Portugal, fundada nas acçoens cristans, moraes, e politicas dos Ecclesiasticos que teve a sua familia. Lisboa: Miguel Rodrigues, 1744.

PORTUGAL, José Miguel João. Instrucçam que o conde de Vimioso Dom Joseph Miguel Joam de Portugal, dá a seu filho D. Francisco Joseph Miguel de Portugal, Fundada nas acçoens moraes, politicas e militares dos Condes de Vimioso seus ascendentes. Lisboa Occidental: Miguel Rodrigues, 1741. PRIORE, Mary del; RASPANTI, Márcia Pinna. Uma Palavra esquecida: decoro. In: História Hoje, 15 jul. 2018. Disponível em: <https://historiahoje. com/uma-palavra-esquecida-decoro/>. Acesso em: 23 abr. 2019.

RAGAZZI, Alexandre. Revista Figura: sobre a constituição, recepção e atualidade da tradição clássica. Concinnitas, v. 1, n. 30, p. 5-14, 2017.

RICHELIEU, Cardeal Duque de. Testamento político. São Paulo: Edipro, 1996. 
SALDANHA, Duarte Rebelo. Illustração medica ethico-politica, historico-sistematica, sceptico-ecletica, físico-analitica e theorico-pratica, ou reflexão critica às considerações médicas. Lisboa: Regia Offic. Silviana, Academia Real, 1761.

SANTOS, Antonio Cesar de Almeida. Decifrando palavras: um vocabulário de cultura e educação no contexto das Luzes portuguesas. In: LAGE, Ana Cristina Pereira (org.). Instituições educativas: cultura, escrita e administração na América portuguesa. Ponta Grossa: Estúdio Texto, 2021. p. 286-313.

SANTOS, Antonio Cesar de Almeida Santos; DENIPOTI, Cláudio; FONSECA, Thaís Nívia de Lima e. Cultura e educação nos impérios ibéricos: pesquisa, teoria, experiência. Antíteses, v. 13, n. 25, p. 567-595, 2020.

SEIXAS, José de Figueiredo. Tratado da ruação para emenda das ruas, das cidades, villas e logares deste reino... [Porto]: [s.n.], [ca. 1760]. Manuscrito.

SILVA, António Delgado da. Collecção da legislação Portugueza desde a última compilação das ordenações: Legislação de 1750 a 1762. Lisboa: Typografia Maigrense, 1830.

SILVA, Antonio de Moraes. Diccionario da lingua portuguesa. Lisboa: Simão Thaddeo Ferreira, 1789.

SERRÃO, Joaquim Veríssimo. O Marquês de Pombal - o homem, o diplomata e o estadista. Lisboa: [s.n.], 1987.

VATTEL, Emer de. O Direito das gentes. Brasília: Editora da Universidade de Brasília, 2004.

VERNEY, Luís Antonio. Verdadeiro método de estudar, para ser útil à República e à Igreja, proporcionado ao estilo e necessidade de Portugal. Valensa: Antonio Balle, 1746.

VITRÚVIO, Marco Lucio. Los Diez libros de arquitectura. Barcelona: Iberia, 1997.

Recebido: 05 maio 2021 | Revisto pelo autor: 05 jul. 2021 | Aceito: 07 jul. 2021 